\title{
The regulation of Krox-20 expression reveals important steps in the control of peripheral glial cell development
}

\author{
Paula Murphy*,1, Piotr Topilko*, Sylvie Schneider-Maunoury*, Tania Seitanidou*, \\ Annick Baron-Van Evercooren ${ }^{\dagger}$ and Patrick Charnay ${ }^{\star}$ \\ *Unité 368 de l'Institut National de la Santé et de la Recherche Médicale, Ecole Normale Supérieure, 46 rue d'Ulm, 75230 Paris \\ Cedex 05, France \\ †Unité 134 de l'Institut National de la Santé et de la Recherche Médicale, Hôpital de la Salpêtrière, 75651 Paris Cedex 13, France \\ ${ }^{1}$ Present address: Biotechnology Centre of Oslo, PO Box 1125, N-0316 Oslo, Norway
}

\section{SUMMARY}

The zinc finger transcription factor gene Krox-20 is expressed in Schwann cells and is required for the myelination of peripheral nerves. We show that the regulation of Krox-20 expression in peripheral glial cells reveals three important steps in the development and differentiation of these cells. (i) Expression of Krox-20 in Schwann cells requires continuous neuronal signalling via direct axonal contact. Therefore Krox-20 appears to be a key component of the transduction cascade linking axonal signalling to myelination. (ii) Krox-20 inducibility is acquired by Schwann cells at the time that they are formed from their precursors. Diffusible factor(s) synthesised by the neural tube can mediate this transition and can be mimicked by
NDF $\beta$ or a combination of CNTF and bFGF. Furthermore, the neural tube activity is blocked by a hybrid protein containing the NDF-binding domain of the ErbB4 receptor, strongly implicating NDF in the physiological transition. (iii) In sensory ganglia, the microenvironment is capable of negatively regulating Krox-20, presumably by preventing the conversion of satellite glial cells toward a Schwann celllike phenotype.

Key words: Schwann cell, satellite cell, myelin, Krox-20, gene disruption, mouse, PNS development, transcription control, NDF, CNTF, FGF

\section{INTRODUCTION}

In vertebrates, the peripheral nervous system (PNS) is mainly derived from the neural crest (Le Douarin et al., 1991; Fraser and Bronner-Fraser, 1991; Frank and Sanes, 1991; Anderson, 1993). Its glial component can be classified into three categories: the Schwann cells surrounding the peripheral nerves, the satellite cells associated with neuronal somata in peripheral ganglia and the enteric glia. Schwann cell development appears to involve at least three steps: the generation of Schwann cell precursors from migrating neural crest cells, the transition of these precursors to Schwann cells and finally the maturation of the latter into myelinating or non-myelinating cells. In the rat, Schwann cell precursors have been characterised as early as embryonic day 14 (E14) as a population of peripheral nerve glial cells that differ from migrating crest cells as well as from differentiated Schwann cells in their morphology, migration behaviour, death regulation and expression of specific molecular markers (Jessen and Mirsky, 1991; Jessen et al., 1994). Between E15 and E17, Schwann cells are irreversibly generated from their precursors and $\beta$ forms of Neu differentiation factor (NDF), also known as glial growth factor (GGF), Heregulin and ARIA (Raff et al., 1978; Holmes et al., 1992; Wen et al., 1992; Falls et al., 1993; Marchionni et al., 1993), have been implicated in the regulation of this conversion in culture (Dong et al., 1995).

Besides dramatic morphological changes, multiple molecular markers are available to characterise the further development of Schwann cells toward the myelinating phenotype, including in particular early myelin proteins, such as myelin-associated glycoprotein (MAG; Owens and Bunge, 1989) and late peripheral myelin proteins, like protein P0 (Brockes et al., 1980). This ultimate differentiation of Schwann cells is thought to be regulated mainly by axon-derived signals (Aguayo et al., 1976; Lemke and Chao, 1988; Trapp et al., 1988; Brunden et al., 1990; Monuki et al., 1990), although the identity of the molecules involved has not yet been determined. In contrast to the transition of precursor to Schwann cell, the maturation of the Schwann cell into a myelin-forming cell is fully reversible as shown following nerve sectioning or in vitro culture in the absence of neurons (Mirsky et al., 1980; Neuberger and Cornbrooks, 1989; Jessen et al., 1990; Jessen and Mirsky, 1991).

We have recently demonstrated that the Krox-20 gene, which encodes a zinc finger transcription factor (Chavrier et al., 1988, 1990), is involved in the control of Schwann cell myelination (Topilko et al., 1994). We have produced a null allele of Krox-20 by in frame insertion of the Escherichia coli 
lacZ gene (Schneider-Maunoury et al., 1993) and have shown that, in the homozygous state, the mutation appears to block Schwann cells at a very precise and early step of their differentiation toward myelin-forming cells; although Schwann cells express MAG, late myelin gene products are absent (Topilko et al., 1994). Mice carrying the lacZ insertion in the Krox-20 locus present no phenotype in the heterozygous state. Since the lacZ expression pattern faithfully reflects that of Krox-20 (Topilko et al., 1994 and data not shown), these mice provide a sensitive and simple system for studying Krox-20 regulation. In heterozygous embryos, $\beta$-galactosidase is first detected in the PNS around 10.5 days post coitum (dpc) in boundary cap cells (Wilkinson et al., 1989; Schneider-Maunoury et al., 1993), which are glial cells found in the sensory and motor roots of both cranial and spinal nerves and are thought to be largely of neural crest origin (D'Amico-Martel and Noden, 1983; Le Douarin, 1986; Le Douarin et al., 1991). Up to 14.5 dpc, Krox-20 expression in the PNS is confined to the nerve roots, with no labelling of the ganglia or of more distal parts of the fibres, with the exception of the XIth cranial nerve (Schneider-Maunoury et al., 1993; Topilko et al., 1994). A major transition occurs around $15.5 \mathrm{dpc}$, when Krox-20/lacZ is activated along the entire length of peripheral nerves. This expression is confined to Schwann cells and activation along the nerves coincides with the transition from precursors to Schwann cells (15.5 dpc in the mouse, which corresponds approximately to E16.5 in the rat). No $\beta$-galactosidase is detected in sensory ganglia or in the sympathetic system.

We have now extended our analysis of the expression of Krox-20/lacZ in Schwann cells. By studying cultures of Schwann cells performed in the presence or absence of neurons and cultures of dorsal root ganglion (DRG) glial cells, we have identified three levels of regulation of Krox-20 expression, which appear to reflect important steps in peripheral glial cell development.

\section{MATERIALS AND METHODS}

\section{Culture conditions}

Standard culture medium for primary new-born Schwann cells, unless otherwise stated, was Dulbecco's modified Eagle's medium (DMEM, Gibco BRL) supplemented with glutamine $(2 \mathrm{mM})$, penicillin (100 $\mathrm{IU} / \mathrm{ml})$, streptomycin $(100 \mathrm{IU} / \mathrm{ml})$, sodium pyruvate $(1 \mathrm{mM})$ and $10 \%$ fetal calf serum (FCS) (all from Gibco BRL). Serum-free defined medium (DM) consisted of a 1:1 mixture of DMEM and Ham's F12 (Gibco BRL) supplemented with selenium $\left(3 \times 10^{-7} \mathrm{M}\right)$, transferrin $(100 \mu \mathrm{g} / \mathrm{ml})$, putrescine $(10 \mu \mathrm{g} / \mathrm{ml})$, progesterone $(60 \mathrm{ng} / \mathrm{ml})$, bovine serum albumin $(0.3 \%)$, insulin $(5 \mu \mathrm{g} / \mathrm{ml})$, glucose $(0.2 \%)$ (all from Sigma), and glutamine, penicillin, streptomycin and sodium pyruvate as above. DRG were cultured as explants either in DMEM, 5\% FCS or DM both supplemented with $1 \mathrm{ng} / \mathrm{ml}$ nerve growth factor (NGF, Sigma). FUDR and forskolin (Sigma) were added to final concentrations of 10 and $5 \mu \mathrm{M}$ respectively. Human NDF $\alpha-2$ and $\beta-2$ recombinant proteins and the polypeptide corresponding to the EGF-like domain of NDF $\beta-2$ were kindly provided by Amgen, CNTF was purchased from Promega, bFGF and IGF-II were from Sigma and LIF from Gibco BRL.

All cultures, except 3-dimensional collagen gels, were performed on glass coverslips treated either with poly-DL-ornithine $(3 \mu \mathrm{g} / \mathrm{ml})$ and laminin $(2 \mu \mathrm{g} / \mathrm{ml})$ (Sigma), or poly-DL-ornithine alone. The presence of laminin changed only the density of axonal outgrowth achieved in DRG explants, Krox-20 induction being equivalent in its presence or absence.
Neural tube cultures required a 3-dimensional collagen support. These cultures were carried out largely following the method of Placzek et al. (1993). Collagen was prepared from rat tail tendons. Explants were assembled as required on a dry collagen-treated culture dish in a drop of liquid collagen in DMEM. The collagen was allowed to set at room temperature for 40 minutes and the cultures were then flooded with medium and incubated at $37^{\circ} \mathrm{C}$. At the end of the required culture period, the explants could be stained for $\beta$-galactosidase activity in situ.

\section{Primary Schwann cell culture and DRG explants}

Schwann cells were prepared from new-born sciatic nerves following the method of Brockes et al. (1979). DRG were dissected from embryos between $12.5 \mathrm{dpc}$ and $17.5 \mathrm{dpc}$ and from new-born mice following removal of the spinal cord from the dorsal aspect. The DRG were then either cut into dorsal and ventral halves or placed whole in culture. If a pure neuronal culture was required, the explants were placed immediately in medium containing FUDR which was alternated with standard medium every 2-3 days. If a culture containing endogenous glia was required, only short pulses of FUDR (12 hours) treatment were administered every 3-4 days.

\section{Revelation of $\beta$-galactosidase activity and immunochemistry}

Cultures were fixed for 5 minutes in $0.2 \%$ glutaraldehyde/PBS, washed twice for 5 minutes in PBS containing $2 \mathrm{mM} \mathrm{MgCl}_{2}, 0.02 \%$ NP40 and $0.1 \%$ sodium deoxycholate and stained in the same solution containing in addition $5 \mathrm{mM} \mathrm{K} 33 \mathrm{Fe}(\mathrm{CN})_{6}, 5 \mathrm{mM} \mathrm{K} 4 \mathrm{Fe}(\mathrm{CN})_{6}$ and 0.4 $\mathrm{mg} / \mathrm{ml} \mathrm{X}$-gal. Staining was carried out at $30^{\circ} \mathrm{C}$ for at least 1 hour but typically overnight. All cultures from the same experiment were stained for the same length of time. Whole embryos were stained as described in Schneider-Maunoury et al. (1993).

The S100 and GalC antibodies were purchased from Sigma. The P0 and MAG antibodies were gifts from B. Trapp. The MBP antibody was a gift from $\mathrm{F}$. Lachapelle. The $2 \mathrm{H} 3$ monoclonal antibody was obtained from the Developmental Studies Hybridoma Bank. The Krox-20 antibody was derived against a Krox-20 bacterial fusion protein (Vesque and Charnay, 1992). Antibodies were applied in PBS/5\% FCS $/ 0.2 \%$ gelatin/0.1\% NP40 usually at a 1:200 dilution (1:50 for Krox-20; 1:500 for S100; 1:5000 for $2 \mathrm{H} 3$ ) for 1.5 hour. The goat anti-rabbit secondary antibody coupled with FITC was purchased from Biosys. Goat anti-rabbit and goat anti-mouse coupled with peroxidase were purchased from Sigma. All secondary antibodies were used diluted 1:200. Slides were either mounted in Mowiol for observation of fluorescence or DAB stained to reveal peroxidase activity. Immunofluorescence of paraffin sections of whole embryos was carried out largely as above with the exception that incubation was overnight with the primary antibody and 4 hours with the secondary antibody.

\section{RESULTS}

\section{Krox-20 is activated in Schwann cells co-cultured with neurons}

In a first series of experiments to analyse the expression of Krox-20 in Schwann cells in vitro, we prepared primary cultures of Schwann cells from sciatic nerves of new-born mice heterozygous for the Krox-20 mutation. When placed in standard culture conditions, these Schwann cells quickly lost Krox-20/lacZ expression, with $\beta$-galactosidase activity no longer detectable after 24 hours (Fig. 1A,B and data not shown). Since the axon is known to regulate a number of important steps in Schwann cell differentiation, new-born Krox-20+/- Schwann cells were co-cultured with wild-type 
sensory neurons. The neuron cultures were derived from 17.5 dpc DRG explants, which were maintained in culture for 3 weeks in the cyclical presence of Fluorodeoxyuridine (FUDR) to eliminate the majority of non-neuronal cells and to obtain an extensive network of naked axons. When primary Schwann cells were seeded onto these neuron cultures, Krox-20/lacZ expression was reactivated within 36 hours (Fig. 1C,D and data not shown).

Co-culture with neurons can lead Schwann cells to undergo the myelination programme (Eldridge et al., 1987, 1989; Morrison et al., 1991). We have looked for the expression of several myelin markers (using antibodies against P0, MBP, MAG, and galactocerebroside (GalC)) in these short-term co-cultures but failed to reveal a detectable level of these antigens (data not shown). Therefore the rapid induction of Krox-20 takes place within a time period that does not allow Schwann cells to fully differentiate and commence myelination of the axons. This is consistent with the requirement for Krox-20 for myelination in vivo (Topilko et al., 1994).

\section{Krox-20 induction requires axonal contact}

Not all of the Schwann cells in a co-culture are induced and, in order to better visualise the relationship between induced Schwann cells and axons, an anti-neurofilament antibody staining was carried out. This showed that strong Krox-20/lacZ induction was only seen in Schwann cells that achieved direct contact with an axon (Fig. 2A,B). The majority of Schwann cells that did not achieve axonal contact were negative for $\beta$ galactosidase activity, while a small minority showed a low level of induction with a surprisingly very localised staining (Fig. 2C,D). The site and origin of this localisation were not investigated further.

To further test the diffusibility of the axonal signal, conditioned medium was prepared from DRG explant cultures. This medium did not induce Krox-20/lacZ when added to primary Schwann cells (data not shown). We also used a 'millicell' system (Millipore) where the DRG explants were grown on a membrane suspended $1 \mathrm{~mm}$ above the floor of the culture dish where the Schwann cells were seeded. In this system, axons do not cross the filter (Bolin and Shooter, 1993), while secreted
Fig. 1. Expression of Krox-20/lacZ in cultured Schwann cells.

$(A, B)$ Primary Schwann cells prepared from Krox$20^{+/-}$new-born pups after 12 (A) or 48 hours (B) of culture; a low level of activity is still detectable in some of the cells after 12 hours (arrow), while at 48 hours all Schwann cells appear negative. (C) DRG explant prepared from a

17.5 dpc wild-type embryo and cultured in the cyclical presence of FUDR for 3 weeks; the axons are largely free of associated glia but a small number of endogenous Schwann-like cells persist (arrow). (D) A parallel DRG explant co-cultured for 48 hours with Krox$20^{+/-}$new-born primary Schwann cells; note the induction of Krox-20/lacZ expression (arrow). (E) 48 hour co-culture of Krox$20^{+/-}$new-born Schwann cells (arrow) with 3 week DRG explants prepared from a 12.5 dpc embryo. The neurons and axons are stained with an antibody directed against neurofilaments (2H3). (F) 48 hour co-culture where the $12.5 \mathrm{dpc}$ wild-

type DRG explant and the Krox-20+/- new-born Schwann cells were simultaneously placed in culture; the axons are relatively inaccessible due to the rich outgrowth of non-neuronal cells from the explant (orange arrow), which can be distinguished morphologically from the added Schwann cells (black arrow) in which Krox-20/lacZ is induced. e, DRG explant; n, neuron; a, axon; scale bars, $30 \mu \mathrm{m}$.
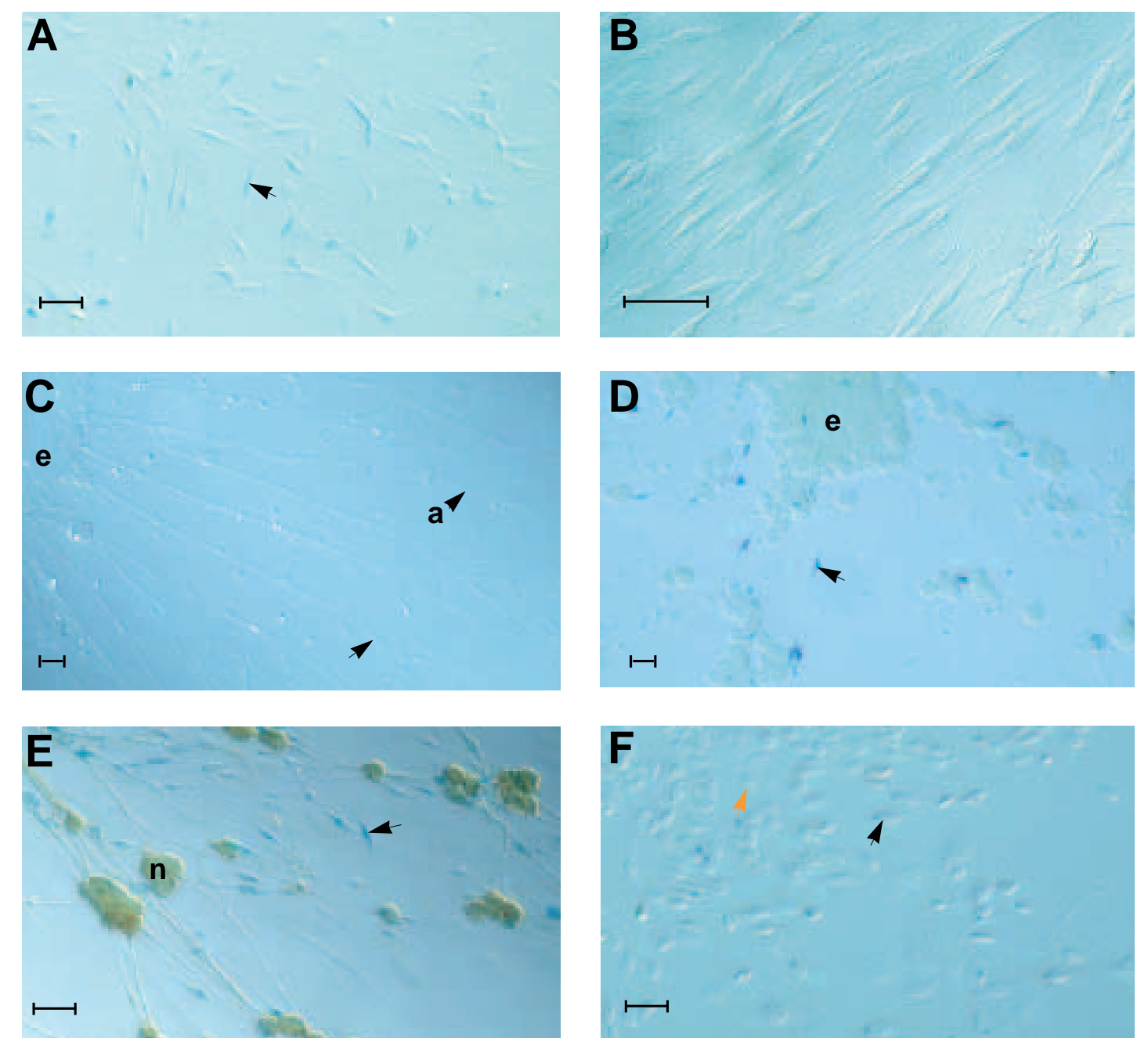

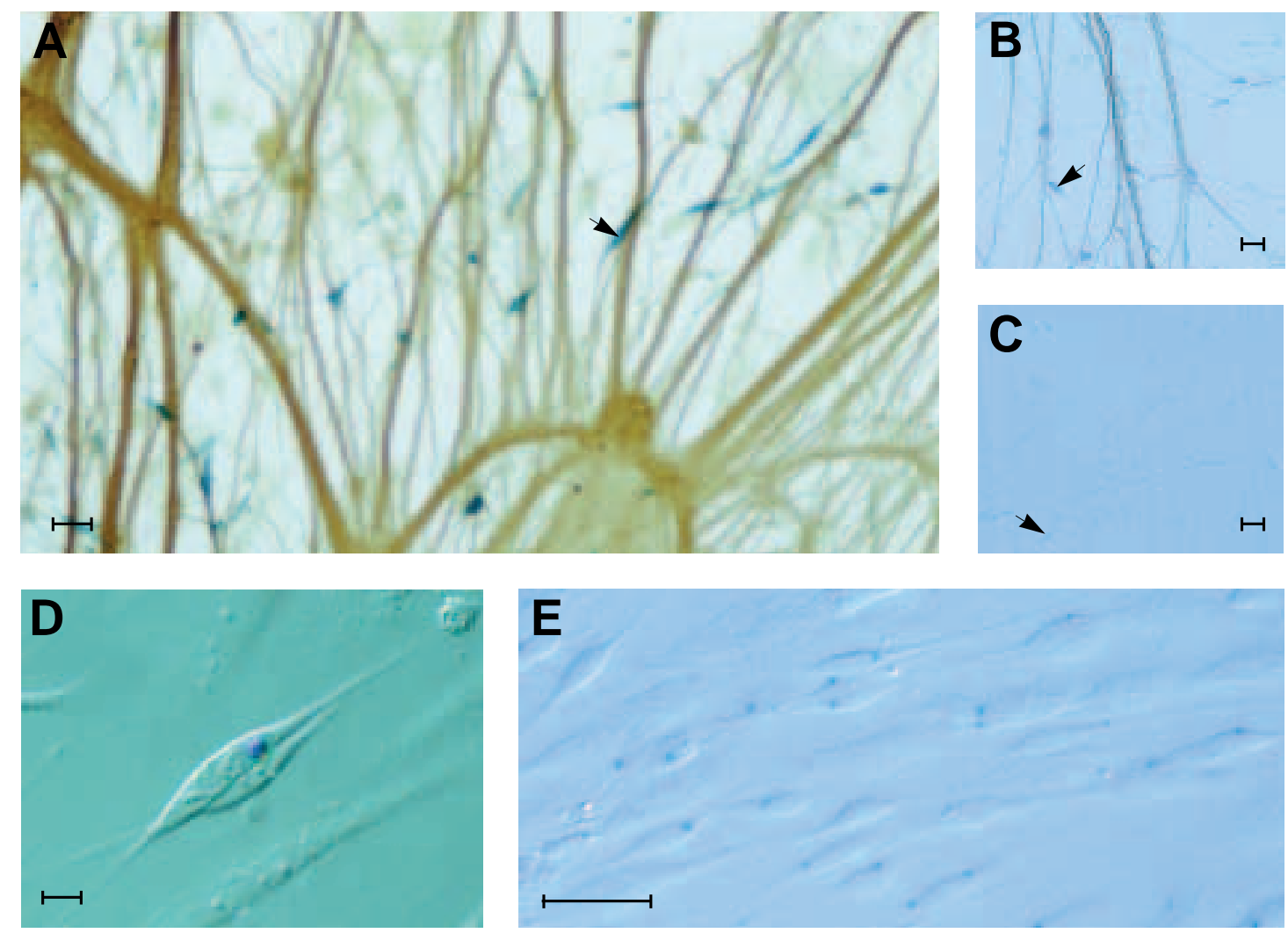

Fig. 2. Efficient induction of Krox-20 in new-born Schwann cells requires axonal contact. (A) 17.5 dpc wild-type DRG explant co-cultured with Krox-20+/- new-born Schwann cells for 48 hours, stained with X-gal and treated with an anti-neurofilament antibody (2H3) to visualise the axons; Krox-20/lacZ expression is observed in the added Schwann cells (arrow). (B-D) Schwann cells (arrows) in the same co-culture either in contact with (B) or distant from (C,D) an axon; in the absence of axonal contact a minority of cells show a low-level, localised staining (arrow in $\mathrm{C}$ and high magnification in D). (E) Co-culture of Schwann cells from Krox-20+/- new-born pups with a 17.5 dpc wild-type DRG explant in the Millicell system for 48 hours. Scale bar, $5 \mu \mathrm{m}$ in D and $30 \mu \mathrm{m}$ otherwise.

macromolecules are free to diffuse. Under these experimental conditions, even after 5 days of co-culture, only a low level of $\beta$-galactosidase activity was detected and the staining was again highly localised (Fig. 2E and data not shown). Altogether, these findings suggest that efficient Krox-20 induction in Schwann cells requires direct axonal contact.

Several Schwann cell markers, including myelin proteins and the POU-domain gene SCIP, that are regulated by axonal signals also respond to changes in intracellular cAMP levels (Lemke and Chao, 1988; Monuki et al., 1989; Weinmaster and Lemke, 1990; Morgan et al., 1991). It has therefore been suggested that increasing cAMP levels mimic axonal signalling. The addition of forskolin $(5-10 \mu \mathrm{M})$ to the culture medium, which effectively increases intracellular cAMP levels, led to a limited induction of Krox-20/lacZ expression within 30 hours, lower than that seen with axonal contact (data not shown). We also tested the ability of a number of growth factors and neurotrophic factors to mimic Krox-20 axonal induction. These factors included brain-derived neurotrophic factor (BDNF), neurotrophin-3 (NT-3), neurotrophin-4 (NT-4), transforming growth factor $\beta 3$ (TGF $\beta 3$ ), glial cell line-derived neurotrophic factor (GDNF), CNTF (all at $1-10 \mathrm{ng} / \mathrm{ml})$, bFGF $(3 \mathrm{ng} / \mathrm{ml}), \mathrm{NDF} \beta-2(10 \mathrm{ng} / \mathrm{ml})$ and bovine pituitary extract $(100 \mu \mathrm{g} / \mathrm{ml})$. None of these factors stimulated Krox-20/lacZ expression in primary Schwann cells (data not shown).

\section{Acquisition of Krox-20 inducibility at 15.5 dpc coincides with precursor to Schwann cell transition}

Since the expression of Krox-20 in the PNS involves axonal signalling, the activation of the gene in vivo at $15.5 \mathrm{dpc}$ raises an important question: is this the consequence of a change in the neurons, which acquire the capacity to provide the signal, or a change in the Schwann cells, which become responsive to a pre-existing axonal signal? To differentiate between these two possibilities, we investigated the capacity of neurons from wild-type DRG collected at different stages of development (i.e. 12.5, 13.5, 14.5, 15.5, $17.5 \mathrm{dpc}$ and new-born DRG) to induce Krox-20/lacZ expression in Schwann cells from new-born Krox-20+/- mice. The explants were maintained in culture for 3 weeks, as described above. Under these co-culture conditions, explants from all stages were capable of inducing Krox-20/lacZ to a similar level (Fig. 1D,E and data not shown), although a greater percentage of Schwann cells seemed to be induced with explants from more advanced stages $(17.5 \mathrm{dpc}$ and new born). This may be due to the larger calibre axons that are produced by developmentally older neurons. To ensure that the capacity of the developmentally younger axons to induce Krox-20 was not due to continued neuronal maturation in culture, $12.5 \mathrm{dpc}$ DRG explants were placed immediately in co-culture with new-born Krox-20+/- Schwann cells and the culture was stained for $\beta$-galactosidase activity after 48 
hours. The axon growth in these cultures was less extensive and the axons were thin and densely packed. There was also a rich growth of endogenous fibroblasts and glial precursor cells, which migrated from the explant covering the axons, thus making contact difficult between the added Schwann cells and the axons. However, where contact occurred, the Schwann cells expressed Krox-20/lacZ, although at a reduced level (Fig. 1F), demonstrating that sensory axons from $12.5 \mathrm{dpc}$ embryos have the capacity to activate Krox20 in new-born Schwann cells and suggesting that in vivo an axonal signal is present from $12.5 \mathrm{dpc}$. Given that Schwann cell precursors are in place along the nerve, presumably from at least $13.5 \mathrm{dpc}$ based on comparison with the rat (Jessen et al., 1994), the appearance of Krox-20 expression along the peripheral nerve only at $15.5 \mathrm{dpc}$ suggests that Schwann cell precursors are not capable of responding to the axonal signal before that time. Acquisition of this capacity appears to be approximately coincidental with the precursor to Schwann cell transition (Jessen et al., 1994).

\section{Precursor to Schwann cell transition occurs earlier within nerve roots}

The observation of early (from $10.5 \mathrm{dpc}$ ) Krox-20 expression in boundary cap and nerve root glial cells (Topilko et al., 1994; Fig. 3A) led us to investigate whether these cells may have reached an advanced stage in their differentiation. To address this question, we examined the expression of S100 within the nerve root, since this marker allows discrimination between Schwann cells and their precursors along the peripheral nerve (Jessen et al., 1994). Immunofluorescence analysis of $12.5 \mathrm{dpc}$ wild-type nerve root sections indicated that S100 was indeed present (Fig. 3B). These data suggest that the glial cells within the nerve roots convert to Schwann cells much earlier than elsewhere.

\section{Krox-20 is rapidly activated in cultured DRG glia}

As indicated above, Krox-20 is never expressed in DRG in vivo, although the glial cells that contact the neuronal cell bodies (satellite cells) constitute a lineage closely related to Schwann cells (Frank and Sanes, 1991; Fraser and Bronner-Fraser, 1991). In vitro culture of DRG has been shown to result in the acquisition by satellite cells of Schwann cell characteristics (Cameron-Curry et al., 1993). To examine the possibility that satellite cells could also be induced to express Krox-20 in vitro, we cultured DRG explants from 17.5 dpc wild-type and Krox$20^{+/-}$embryos and examined Krox-20 and Krox-20/lacZ expression respectively (the Krox-20 protein was detected by immunocytochemistry using a rabbit polyclonal antibody raised against a Krox-20 fusion protein (Vesque and Charnay, 1992)). The explants were treated with brief (12 hours) pulses of FUDR in order to restrict fibroblast growth but to allow survival of glial cells. While both Krox-20 and Krox-20/ $\beta$-gal could not be detected in freshly explanted DRG, after culture for 48 hours expression was observed throughout the ganglionic glia (Fig. 4A-E) and Krox-20/lacZ expression was detected within the explant 6 hours after initiation of the culture (data not shown). After about 36 hours of culture, $\beta$-galactosidase-positive glial cells migrated out from the explant to populate the growing axons (Fig. 4E). Within the explant, expression was not restricted to cells positioned along the axons but was also detected in satellite cells in contact with neuronal cell bodies,
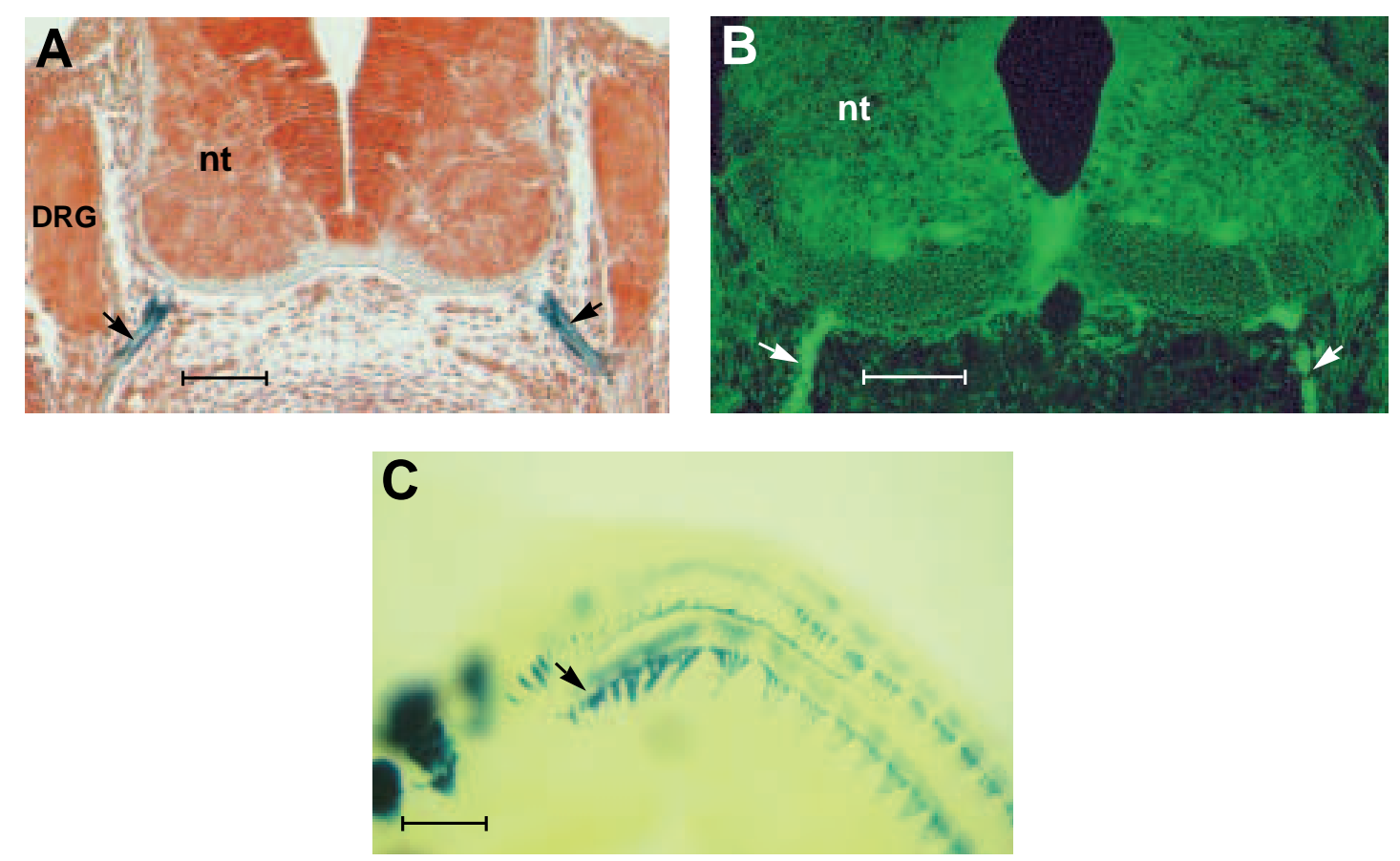

Fig. 3. Expression of mature Schwann cell markers occurs in vivo in specific populations of peripheral glia cells before 15.5 dpc. (A) Transverse section of an $11.5 \mathrm{dpc}$ Krox $-20^{+/-}$embryo showing Krox-20/lacZ expression in the ventral nerve roots close to the neural tube (arrows). (B) Immunofluorescence analysis of a transverse section of a $12.5 \mathrm{dpc}$ wild-type embryo showing that S100 is also expressed in the nerve roots (arrows). (C) Whole-mount X-gal staining of an $11.5 \mathrm{dpc}$ Krox-20 $0^{+/-}$embryo showing Krox-20/lacZ expression in a portion of the XIth nerve, which runs parallel and close to the neural tube up to the level indicated by the arrow. Rostral is to the left, dorsal to the top. nt, neural tube; scale bars, $200 \mu \mathrm{m}(\mathrm{A}, \mathrm{B})$ and $500 \mu \mathrm{m}(\mathrm{C})$. 

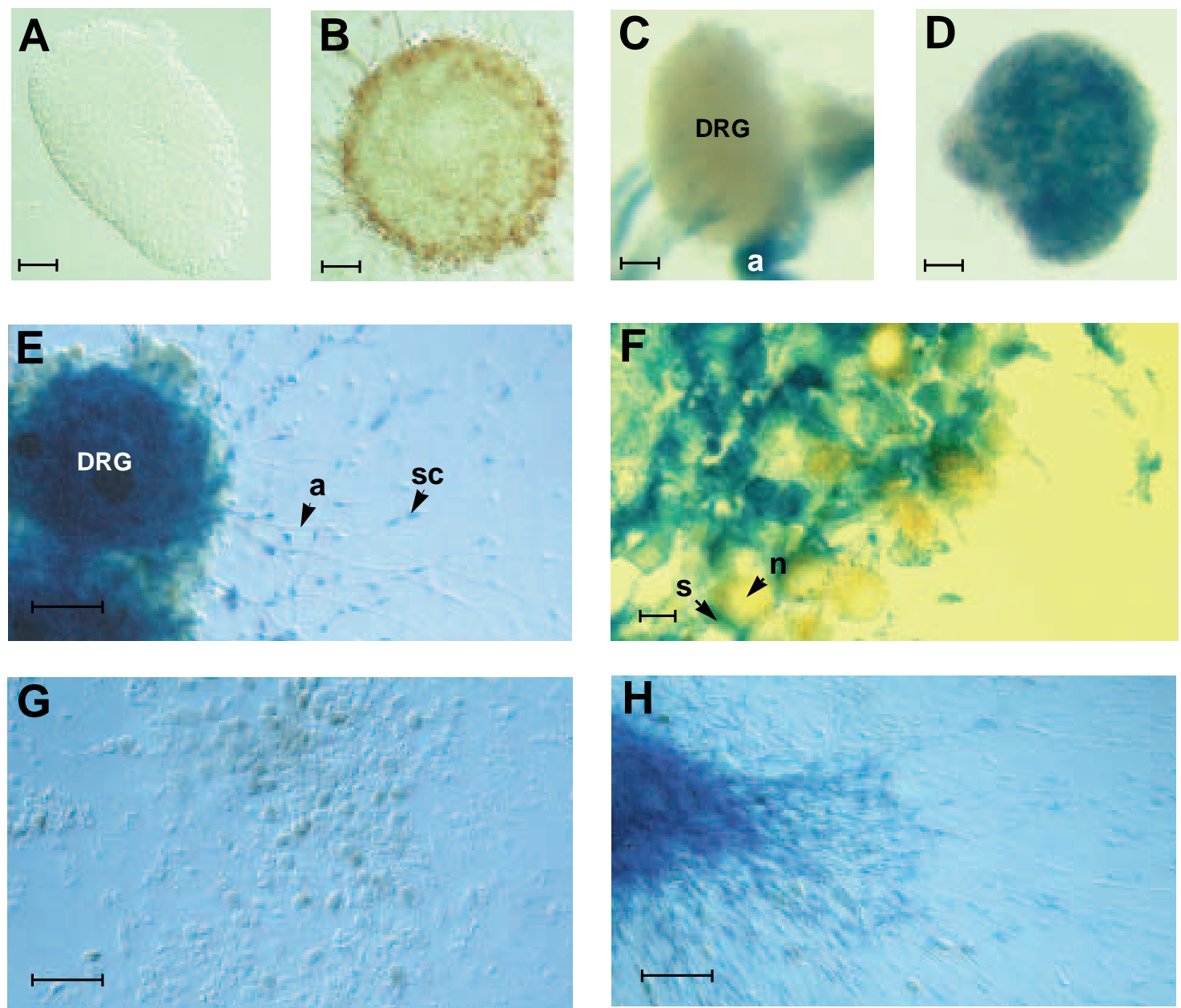

Fig. 4. Krox-20 expression in cultured DRG glia. (A,B) DRG explants from a 17.5 dpc wild-type embryo stained with an antibody directed against Krox-20, immediately after dissection (A) or cultured for 48 hours (B). (C-E) DRG explants from a $17.5 \mathrm{dpc}$ Krox-20 $0^{+/-}$embryo stained for $\beta$-galactosidase activity immediately after dissection (C; note that X-gal staining is restricted to the attached bundles of axons) or cultured for 18 (D) or 48 hours (E); the 48 hours culture shows that Krox-20/lacZ is expressed by Schwann-like cells that have migrated along the axons as well as by the glia in the explant itself. (F) Section of a $17.5 \mathrm{dpc}$ DRG explant cultured for 48 hours showing that expression is not detected in the anti-neurofilament positive neuronal cell bodies but is observed in the closely associated glia. (G,H) Comparison of Krox20/lacZ expression in DRG explants prepared from Krox $-20^{+/-}$embryos at $12.5 \mathrm{dpc}(\mathrm{G})$ or $15.5 \mathrm{dpc}(\mathrm{H})$ and cultured for 48 hours. a, axon; sc, Schwann-like cell; DRG, dorsal root ganglion; n, neuronal cell body; s, satellite cell; scale bar, $10 \mu \mathrm{m}$ in F and $100 \mu \mathrm{m}$ otherwise.

while the neurons themselves were negative (Fig. 4F). In conclusion, these data indicate that DRG culture leads to massive induction of Krox-20 in the glial component. In addition, the detection of Krox-20 in wild-type DRG cultures confirms that the $\beta$-galactosidase activity in heterozygous explants faithfully reflects the Krox-20 expression pattern.

\section{A transition occurs within DRG glia around 15.5 dpc}

To investigate when DRG glial cells acquire the capacity to activate Krox-20 in vitro, we compared DRG explant cultures from Krox-20 $0^{+/-} 12.5,13.5,14.5,15.5,17.5 \mathrm{dpc}$ embryos and new-born mice. These cultures differed dramatically in both their capacity to express Krox-20/lacZ and in the morphology of their migrating glial cells depending on whether they were prepared before or after $15.5 \mathrm{dpc}$. With DRG collected before $15.5 \mathrm{dpc}$, the glial cells did not express Krox-20/lacZ for at least 48 hours in culture, even when in contact with axons, and the migrating cells had a flattened morphology (Fig. 4G and data not shown). From $15.5 \mathrm{dpc}, \beta$-galactosidase activity was detected within the explant from 6 hours of culture (data not shown). The migrating cells expressed Krox-20/lacZ, showed the typical elongated, bipolar, Schwann cell morphology and extended themselves along the axons (Fig. 4H). This suggests that an important transition event in the development of DRG glial cells takes place around $15.5 \mathrm{dpc}$ in the mouse. Such a modification appears similar to the transition of precursor to Schwann cell and may be required for Krox-20 activation in response to axonal signalling.

\section{Diffusible factor(s) produced by the neural tube can induce Krox-20 expression in $12.5 \mathrm{dpc}$ satellite cells}

As indicated above, a restricted population of glial cells within the nerve roots express Krox-20 from 10.5 dpc (Fig. 3A). In addition, the gene is also expressed in the portion of the XIth nerve lying close to the neural tube (Fig. 3C). These observations raise the possibility that the neural tube may exert an 
influence on Schwann cell precursors in its vicinity and induce the expression of Krox-20. To explore such a possibility, given the technical difficulties involved in isolating Schwann cell precursors in the mouse embryo, we examined the effect of the neural tube on glial cells in DRG explants, which we had previously established behave like Schwann cell precursors in culture. Co-culture experiments were performed in 3-dimensional collagen gels with $12.5 \mathrm{dpc}$ DRG, which do not express Krox-20 in vitro, using the ventral half of the DRG to eliminate any spontaneously blue cells possibly originating from the nerve root. The neural tube explants were prepared from $10.5 \mathrm{dpc}$ wildtype embryos and consisted of the region from rhombomere 5 to the level of the anterior limb bud, opened at the dorsal midline. Under these circumstances, after a culture period of 48 hours, the presence of the neural tube led to a dramatic activation of Krox-20/lacZ in the DRG explants (Fig. 5A-C).

To test whether the signal provided by the neural tube is a freely diffusible factor, we: (i) placed the DRG explants at a distance from the neural tube, (ii) inserted a 'biopore' filter (pore size, $0.2 \mu \mathrm{m}$ ) between the neural tube and the DRG explant, and (iii) grew the DRG explants in the presence of neural tube conditioned medium. In all three circumstances Krox-20 induction was achieved within 48 hours (Fig. 5D,E and data not shown). The extent of induction was quantitatively affected by the distance from the neural tube explant: whereas a distance of 200 $\mu \mathrm{m}$ or less led to a strong induction, a separation of $500 \mu \mathrm{m}$ gave a visibly weaker effect. These data demonstrate that the neural tube produces diffusible factor(s) that can activate Krox-20 expression in $12.5 \mathrm{dpc}$ glial cells in culture.

\section{NDF $\beta$ is a major component of the neural-tube- inducing activity}

A number of factors were tested for their ability to reproduce the effect of the neural tube factor(s) on $12.5 \mathrm{dpc}$ DRG explants. These included bFGF (3 ng/ml), NGF, BDNF, NT-3, NT-4, CNTF, GDNF, NDF $\alpha-2$ and NDF $\beta-2$ (each at $10 \mathrm{ng} / \mathrm{ml}$ ), leukemia inhibitory factor (LIF, $1000 \mathrm{U} / \mathrm{ml}$ ) and bovine pituitary extract $(100 \mu \mathrm{g} / \mathrm{ml})$. While various effects were
Fig. 5. Krox-20 is induced in $12.5 \mathrm{dpc}$ DRG glia by diffusible factor(s) from the neural tube. (A) Explant prepared from the ventral half of a $12.5 \mathrm{dpc}$ Krox- $20^{+/-}$DRG cultured in a 3-dimensional collagen gel for 48 hours. (B) 4 sister explants to that shown in A (arrows) co-cultured with a $10.5 \mathrm{dpc}$ wild-type neural tube. (C) Section of the co-culture shown in B, counter-stained with saphranine, showing expression of Krox-20/lacZ in the ganglionic glia and the migrating glial cells. (D) Co-culture similar to that shown in B where DRG explants (arrows) have been separated from the neural tube by a biopore filter $(0.2 \mu \mathrm{m}$ pore size $)$ and a distance of approximately $150 \mu \mathrm{m}$. (E) DRG explant similar to that shown in A which has been cultured in neural tube-conditioned medium for 48 hours. nt, neural tube; scale bars, $100 \mu \mathrm{m}$.
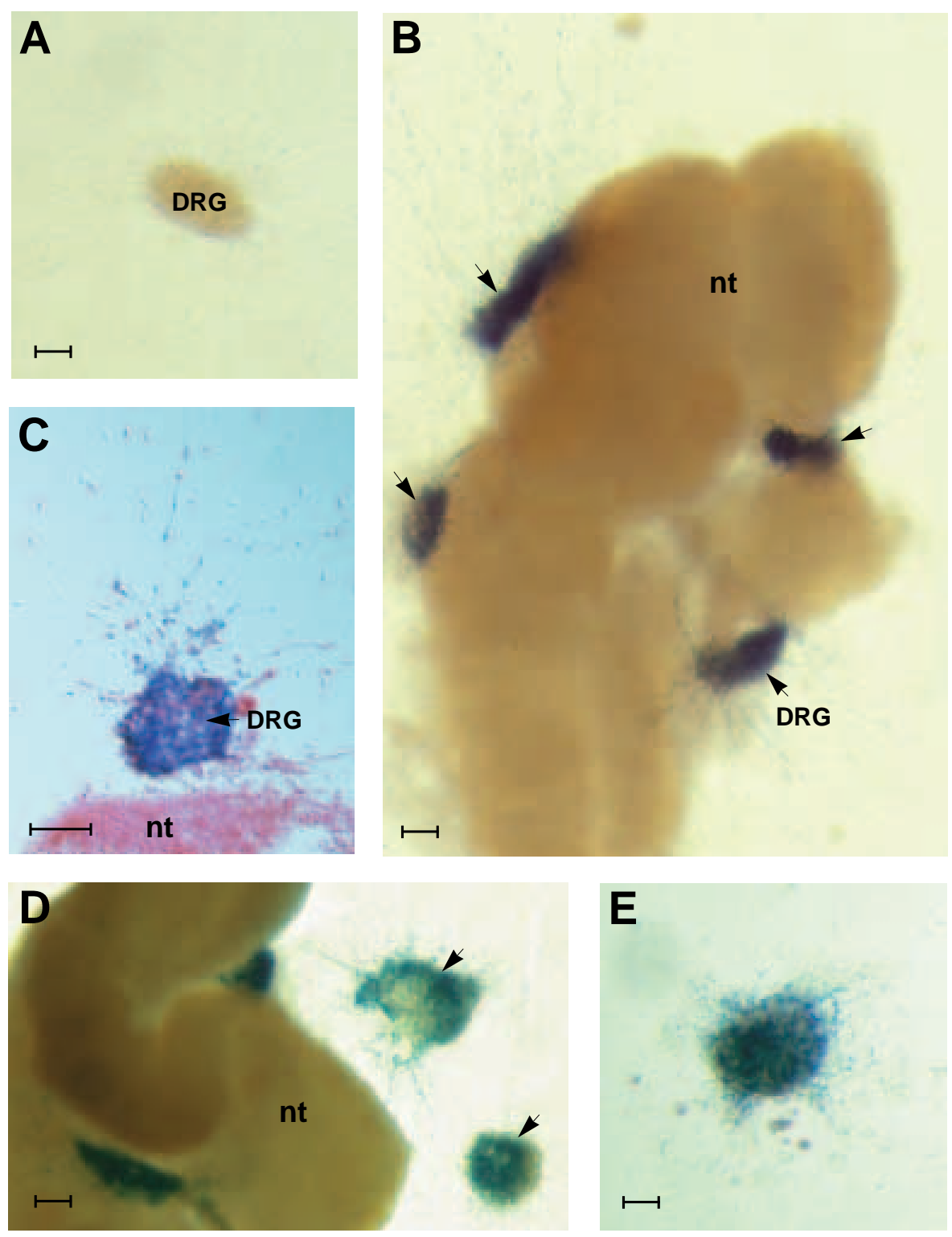
observed on the rate and density of axonal outgrowth with these different factors (data not shown), only CNTF, LIF, bFGF and NDF $\beta$-2 had an influence on Krox-20/lacZ expression. CNTF and LIF treatment for 48 hours consistently induced expression to a clearly detectable level and varying the concentration of CNTF between 10 and $100 \mathrm{ng} / \mathrm{ml}$ did not significantly change the level of response (Fig. 6B and data not shown). The level of induction obtained with each of these factors alone was lower than the level achieved in co-cultures with the neural tube. bFGF alone had little or no effect on Krox-20 expression. However, when bFGF $(3 \mathrm{ng} / \mathrm{ml})$ was added in the presence of CNTF (10 ng/ml) or of LIF, a strong synergistic effect was observed (Fig. 6B,C and data not shown). NDF $3-2$ alone was also able to strongly activate Krox-20/lacZ expression and the effect was dose-dependant (Fig. 6D and data not shown). A polypeptide corresponding to the epidermal growth factor (EGF)-like domain of NDF $\beta-2$ (residues 177-228) led to significant induction at a concentration of $1 \mathrm{ng} / \mathrm{ml}$ and to strong activation at $10 \mathrm{ng} / \mathrm{ml}$ (data not shown). Therefore the effect of the neural tube factor(s) on $12.5 \mathrm{dpc}$ DRG explants can be reproduced with NDF $\beta-2$ or a combination of CNTF and bFGF.

To directly investigate the possibility that NDF $\beta$ might be the inducing factor produced by the neural tube, we performed blocking experiments with a soluble hybrid protein containing the extracellular domain of the ErbB4 NDF receptor, which was shown to specifically block the action of NDF (Dong et al., 1995). Addition of this protein at a concentration of $2 \mu \mathrm{g} / \mathrm{ml}$ resulted in a strong inhibition of Krox-20/lacZ activation by either purified NDF $\beta$ or neural tube-conditioned medium (Fig. 6E,F and data not shown). However, a low level of activation was achieved with both inducers even in the presence of the soluble receptor (Fig. 6F and data not shown). We conclude that NDF constitutes a major component of the inducing activity present in the neural tube conditioned medium.

\section{DISCUSSION}

\section{Krox-20 mediates axonal signalling to the Schwann cell nucleus}

The differentiation of Schwann cells into myelin-forming cells depends on continuous signalling from the axon: myelinforming Schwann cells, when removed from an axonal influence, continue to express S100, but the myelination process is reversed and the expression of corresponding markers is lost. Here we show that Krox-20 also depends on axonal contact for continued high expression in Schwann cells. As in the case of the peripheral myelin protein P0 gene (Bolin and Shooter, 1993), a weak activation of Krox-20 expression is nevertheless observed in the presence of neurons in the Millicell culture system, which prevents direct axonal contact. These data suggest that at least one of the neuronal factors required for Krox-20 induction is membrane-bound, has a very limited diffusibility or is highly unstable.

Analysis of Krox $-20^{-1-}$ mutant mice revealed that Krox-20 is required for the completion of the myelination process in the PNS and that its absence prevents the activation of late myelin markers, including P0 (Topilko et al., 1994). The combination of these data with the present study suggests that one function of Krox-20 in Schwann cells is to transmit an axonal signal to the nucleus, which is continuously required to express part of the genetic programme necessary for myelination. This pre-
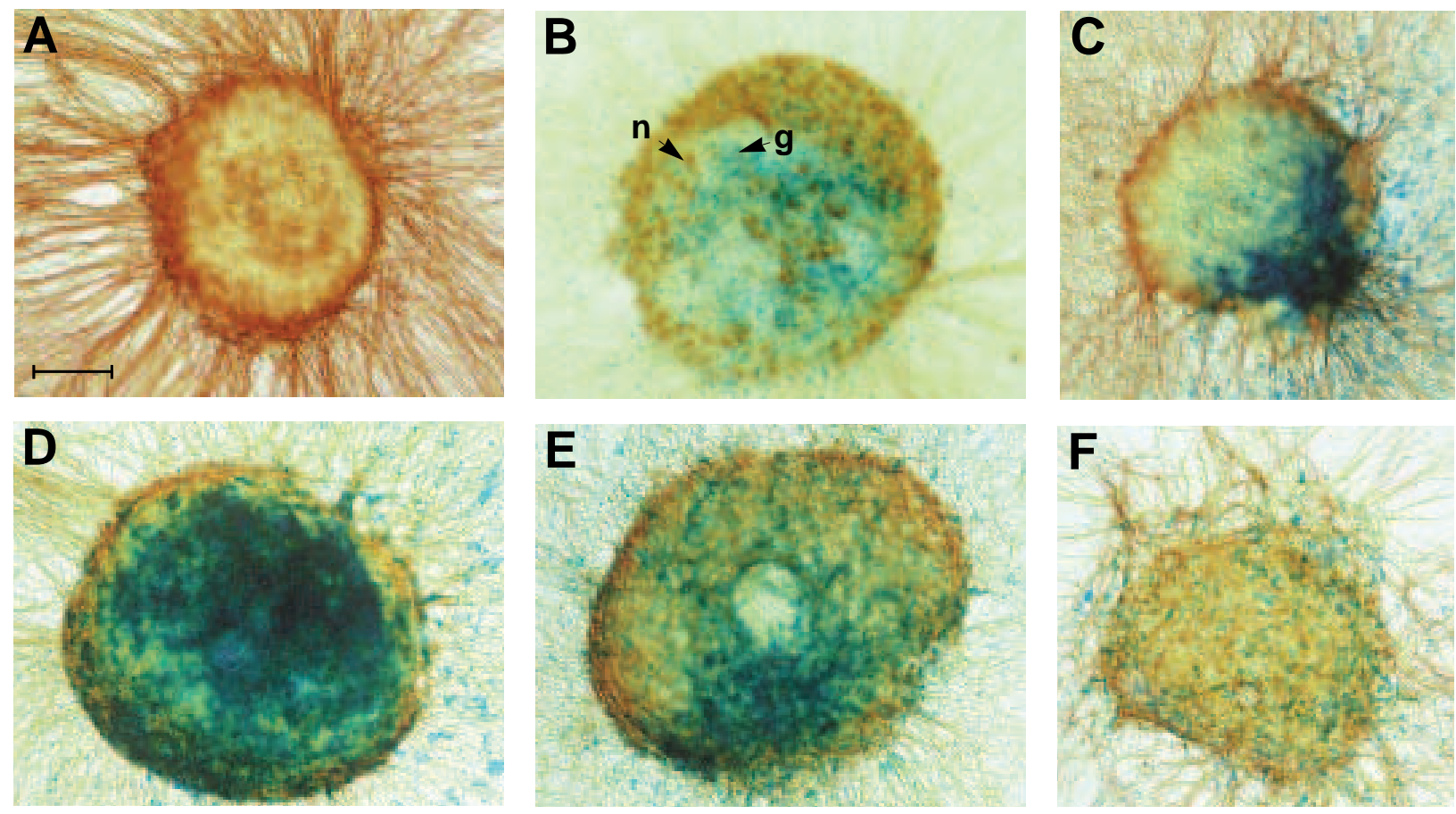

Fig. 6. Krox-20 is induced by NDF $\beta-2$ alone and synergistically by CNTF and bFGF in $12.5 \mathrm{dpc}$ DRG explants. (A-F) $12.5 \mathrm{dpc}$ Krox-20+/DRG explants stained for $\beta$-galactosidase activity and with an anti-neurofilament antibody (2H3), after 48 hours culture in serum-free defined medium supplemented with NGF alone (A), or NGF and the following additives: CNTF (10 ng/ml) (B), CNTF (10 ng/ml) plus bFGF (3 ng/ml) (C), NDF $\beta$-2 protein (100 ng/ml) (D), neural-tube-conditioned medium (E), neural-tube-conditioned-medium plus a hybrid protein containing the extracellular domain of the ErbB4 NDF receptor $(2 \mu \mathrm{g} / \mathrm{ml})(\mathrm{F})$. n, neuronal cell body; g, glia; scale bar, $60 \mu \mathrm{m}$. 
Fig. 7. Schematic representation of the development and differentiation of Schwann and satellite cells from their neural crest precursors. The three levels of regulation acting on Krox-20 expression are indicated. See the discussion section for details of the model. Although S100 expression does not require Krox-20 activation, the relative timing of their expression in vivo is not known. The existence of the satellite to Schwann cell conversion is hypothetical and the possible generation of a cell type distinct from Schwann cells upon culture of satellite cell is not represented for reasons of simplicity. Single arrows indicate irreversible processes, while double arrows indicate reversible transitions or conversions. Presence of Krox-20 in the nucleus and of S100 in the cytoplasm are indicated in blue and yellow respectively. Axons are represented in red. NC, neural crest cell; SCpr, Schwann cell precursor; SC,

Schwann cell; MSC, myelinating Schwann cell; Sat pr, satellite cell precursor; Sat, satellite cell; $n$, nucleus; a, axon.

sumably involves the direct transcriptional activation of a set of genes by Krox-20. Whether the late myelination markers are among these direct targets is not yet known.

\section{Acquisition of Krox-20 inducibility is part of the precursor to Schwann cell transition}

Our co-culture experiments suggest that the induction of Krox20 along peripheral nerves at around $15.5 \mathrm{dpc}$ is not directly due to a change in signalling from the neurons, but rather to a modification of the Schwann cells themselves, which allows them to respond to an axonal signal that pre-exists. However, our experiments do not address the possibility that this modification of the Schwann cells may actually be induced by the neurons. Several arguments issued from the present work suggest that the acquisition of Krox-20 inducibility is part of the precursor to Schwann cell transition. (i) This event occurs along peripheral nerves at around the same time as the transition, i.e. $15.5 \mathrm{dpc}$, as estimated from the work in rat (Jessen et al., 1994). (ii) In nerve root glial cells, Krox-20 activation occurs at $10.5 \mathrm{dpc}$, raising the possibility that in this microenvironment, the precursor to Schwann cell transition might occur much earlier than elsewhere. In the PNS, the S100 protein appears to mark this transition (Jessen et al., 1994). We have found that early nerve roots express S100, suggesting that the transition has indeed occurred. The possible functional significance of this localised early transition is so far unknown. (iii) The capacity of glia from sensory ganglia to activate Krox20 in culture is also acquired at around $15.5 \mathrm{dpc}$. This might again involve a transition, from precursor to mature satellite cells, with the same timing and possibly under the control of the same regulators as the precursor to Schwann cell transition. Indeed we have shown that NDF $\beta-2$, which has been found to promote the precursor to Schwann cell transition in vitro (Dong et al., 1995), also activates Krox-20 expression in early ganglia in culture. The concentration of NDF $\beta-2$ effective for Krox-20 activation in $12.5 \mathrm{dpc}$ DRG explants (in the range of $200 \mathrm{pM}$ ) is similar to that required for the full modification of Schwann cell precursor properties in vitro (Dong et al., 1995). Furthermore, the EGF-like domain (residues 177-228) is sufficient for the two types of induction phenomena.

In conclusion, we propose that the capacity to activate Krox-

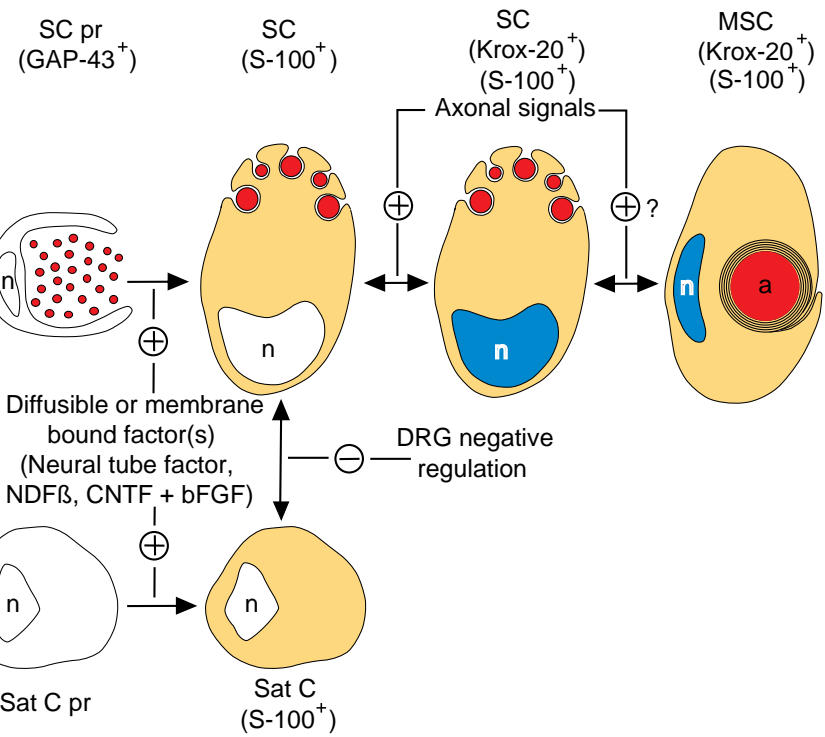

20 in response to axonal signalling is characteristic of the Schwann cell as opposed to its precursor. One possible mechanism for this would be that the transition to the mature Schwann cell involves the expression of a molecule required for the reception or transduction of the axonal signal. In any case, the expression of Krox-20 itself does not appear to be required for the acquisition of the characteristic survival and proliferation capacities of mature Schwann cells, since these are observed in the absence of axonal signalling (Dong et al., 1995). Furthermore, Schwann cells from homozygous Krox-20 mutant mice express S100 (Topilko et al., 1994).

\section{Factors regulating Krox-20 expression and glial cell maturation}

The results of our experiments demonstrate that diffusible factor(s) from the $10.5 \mathrm{dpc}$ neural tube induce Krox-20 expression in the glial cells of $12.5 \mathrm{dpc}$ DRG explants. We propose that this activation is the result of the combination of two modifications occurring in these cells, followed by axonal signalling: (1) a precursor to satellite cell transition, induced by the neural tube factor, and (2) a modification of the satellite cell phenotype, which is allowed by in vitro culture and involves a release of Krox-20 repression.

At present, we do not know whether the factors responsible for the neural tube activity measured in our in vitro system, for the early expression of Krox-20 in boundary cap cells and for its late activation in Schwann cells are identical. Nevertheless NDF $\beta$ appears to be a good candidate for mediating the activation of Krox-20 in these different situations. (i) We have established that NDF $\beta$ is the major component of the inducing activity originating from the neural tube measured in our assay. (ii) NDF $\beta$ has been shown recently to regulate survival, proliferation and lineage progression of rat Schwann cell precursors (Dong et al., 1995) and inactivation of its gene was shown to prevent normal development of Schwann cell precursors (Meyer and Birchmeier, 1995). (iii) The known expression sites of the NDF gene, including in particular the spinal motor neurons and DRG neurons (Marchionni et al., 1993; OrrUrtreger et al., 1993; Meyer and Birchmeier, 1994), are consistent with a role in the activation of Krox-20 in the PNS. We propose the following hypothesis for the activation of Krox-20 
in two phases during PNS development: at early stages (i.e. 10.5 to $15.5 \mathrm{dpc}$ ), due to specific splicing, NDF $\beta$ might be expressed as a secreted molecule and released by the soma of the neurons from the neural tube and possibly from the DRG, therefore acting only locally on the Schwann cell precursors in the nerve roots. From $15.5 \mathrm{dpc}$, a modification of the splicing pattern might occur, resulting in the synthesis of a membranebound form of NDF $\beta$ which would reach the axons and therefore be able to stimulate Schwann cell precursors along the nerves. Analysis of the specific expression of the different isoforms of NDF should allow this hypothesis to be tested.

Although the case of NDF $\beta$ is strong, an involvement of other factors in the maturation of Schwann cells is also worth consideration. It has been shown that bFGF alone can promote precursor to Schwann cell transition as assayed by cell survival in vitro and morphological modifications (Jessen et al., 1994; Gavrilovic et al., 1995). However, recent studies have shown that this effect is only transient and that long-term survival requires co-operation between bFGF and other serum factors (Dong et al., 1995). In our assay, bFGF alone is only very weakly active, but it can act synergistically with other factors to induce Krox-20 expression. This observation again reinforces the parallel between our assay involving $12.5 \mathrm{dpc}$ ganglia and the maturation of rat Schwann cell precursors. In this respect, it will be interesting to determine whether the combination of bFGF with CNTF or LIF allows long-term survival of Schwann cell precursors.

\section{Krox-20 negative regulation in peripheral ganglia may reflect the specification of the glial cell phenotype by the microenvironment}

The observation of a massive and very rapid induction of Krox20 expression in the glial component of explanted DRG, which cannot simply be due to an expansion of a subpopulation of Schwann cells, indicates that Krox-20 activation occurs in the satellite cells. This regulation of Krox-20 expression in satellite cells could be explained in two ways. (i) The explantation of the DRG and/or the exposure of the cells to culture medium could result in the activation of Krox-20 via a positive regulatory mechanism. It is in fact known that axotomy induces morphological and biochemical changes in the neuronal cell body and that these changes are reflected in the behaviour of the satellite cells (Wen et al., 1994). (ii) An alternative hypothesis is that, in the in vivo environment of the DRG, Krox-20 is subject to negative regulation in satellite cells and that disruption of DRG structure in culture results in derepression. We favour the second hypothesis since Krox-20 activation occurs in very short-term culture and is observed in culture with serum-free defined medium.

The observation that Krox-20 activation, which is restricted to Schwann cells in the PNS in vivo, can occur in DRG satellite cells in culture raises the possibility that this phenomenon may reflect a more profound modification of satellite cells, corresponding to a conversion to the Schwann cell-like phenotype. As mentioned previously, satellite cells are closely related to Schwann cells in term of lineage. Furthermore, our observation that in vitro culture cannot activate Krox-20 in DRG explanted before $15.5 \mathrm{dpc}$ suggests that satellite cells presumably undergo a transition from precursors to mature cells in a similar way to Schwann cells. These transitions occur approximately at the same time for the two glial cell types and can be mediated by the same factor (NDF $\beta-2)$, indicating that the precursor cells present in the peripheral nerves and sensory ganglia share similar properties. DRG explants constitute rich sources of Schwann cells in culture and these may be partly generated from the satellite cells (Wood, 1976). In addition, in the avian PNS, the Schwann cell myelin protein (SMP) gene, which is expressed exclusively by Schwann cells in vivo (Dulac et al., 1988), can be activated in DRG satellite cells in vitro (Cameron-Curry et al., 1993). These data support the idea that different types of glia are derived from a common lineage and differentiate according to microenvironmental influences and that conversion between the alternative cell types is possible when environmental signalling is modified. In conclusion, our results are consistent with the occurrence of a satellite to Schwann cell conversion upon DRG culture, involving the release of Krox-20 repression.

\section{Conclusion: three levels of $K r o x-20$ regulation in peripheral glia reflect important developmental steps}

Despite the availability of several molecular markers, our knowledge of the molecular and cellular mechanisms controlling the development of peripheral glia is very limited. In the present paper, we have provided evidence for the existence of three levels of control of Krox-20 gene expression in PNS glial cells, which are schematically depicted in Fig. 7. We have shown that the regulation of Krox-20 expression is linked to three fundamental developmental steps: (i) the maturation of glial cells from their precursors, (ii) a modification of satellite cells, which may consist in a conversion into Schwann cells, and (iii) axonal signalling, which mediates the activation of the myelination programme. It is interesting to note that the activation of Krox20 in Schwann cell precursors might actually require two ordered signals from the axon: the first one may correspond to $\mathrm{NDF} \beta$ and leads to an irreversible transition toward mature Schwann cells and the second one is presumably membranebound and engages the cells into a reversible differentiation process. The availability of a simple and sensitive assay for Krox-20 expression has allowed us to initiate the analysis of some aspects of Schwann cell development. Future exploitation of this system may provide access to additional molecular regulators of the Schwann cell developmental pathway.

We are in debt toward the deceased P. Cameron-Curry for advice on Schwann cell culture methods. We thank B. Allinquant and I. LeRoux for advice on neuron cultures, C. Vesque and M. Placzek for help in establishing the 3-dimensional collagen gel cultures, F. Lachapelle and B. Trapp for antibodies and C. Henderson and B. Zalc for helpful discussions and critical comments on the manuscript. NDF proteins and peptide were kindly provided by Dr Ratzkin (Amgen Inc.). The extracellular domain of the ErbB4 NDF receptor was a kind gift of Dr Y. Yarden. The $2 \mathrm{H} 3$ monoclonal antibody was obtained from the Developmental Studies Hybridoma Bank maintained by the Department of Pharmacology and Molecular Sciences, Johns Hopkins University School of Medicine, and the Department of Biological Sciences, University of Iowa, under contract N01-HD-6-2915 from the NICHHD. This work was supported by grants from INSERM, EEC, ARC, LNFCC, AFM and ARSEP. P. M., P. T. and T. S. were supported by postdoctoral fellowships from the Human Frontier Science Programme, AFM and Recherche et Partage respectively. 


\section{REFERENCES}

Aguayo, A. J., Epps, J., Charron, L. and Bray, G. M. (1976) Multipotentiality of Schwann cells in cross-anastomosed and grafted myelinated and unmyelinated nerves: quantitative microscopy and radioautography. Brain Research 104, 1-20.

Anderson, D. J. (1993). Cell and molecular biology of neural crest cell lineage diversification. Curr. Opinion Neurobiol. 3, 8-13.

Bolin, L. M. and Shooter, E. M. (1993). Neurons regulate Schwann cell genes by diffusible molecules. J. Cell Biol. 123, 237-243.

Brockes, J. P., Fields, K. L. and Raff, M. C. (1979). Studies on cultured rat Schwann cells. I. Establishment of purified populations from cultures of peripheral nerve. Brain Research 165, 105-118.

Brockes, J. P., Raff, M. C., Nishiguchi, D. J. and Winter, J. (1980). Studies on cultured rat Schwann cells. III. Assays for peripheral myelin proteins. $J$. Neurocytology 9, 67-77.

Brunden, K. R., Windebank, A. J. and Poduslo, J. F. (1990). Role of axons in the regulation of P0 biosynthesis by Schwann cells. J. Neuroscience 26, 135-143.

Cameron-Curry, P., Dulac, C. and Le Douarin, N. M. (1993). Negative regulation of Schwann cell myelin protein gene expression by the dorsal root ganglionic microenvironment. Eur. J. Neurosci. 5, 594-604.

Chavrier, P. Zerial, M., Lemaire, P., Almendral, J., Bravo, R. and Charnay, P. (1988). A gene encoding a protein with zinc fingers is activated during G0/G1 transition in cultured cells. EMBO J. 7, 29-35.

Chavrier, P., Vesque, C. Galliot, B., Vigneron, M., Dollé, P., Duboule, D. and Charnay, P. (1990). The segment-specific gene Krox-20 encodes a transcription factor with binding sites in the promoter region of the Hox-1. 4 gene. EMBO J. 9, 1209-1218.

D’Amico-Martel, A. and Noden, D. M. (1983). Contributions of placodal and neural crest cells to avian cranial peripheral ganglia. Amer. J. Anat. 166, 445468.

Dong, Z., Brennan, A., Liu, N., Yarden, Y., Lefkowitz, G., Mirsky, R. and Jessen, K. R. (1995). Neu differentiation factor is a neuron-glia signal and regulates survival, proliferation, and maturation of rat Schwann cell precursors. Neuron 15, 585-596.

Dulac, C., Cameron-Curry, P., Ziller, C. and Le Douarin, N. M. (1988). A surface protein expressed by avian myelinating and nonmyelinating Schwann cells but not by satellite or enteric glial cells. Neuron 1, 211-20.

Eldridge, C. F., Bunge, M. B., Bunge, R. P. and Wood, P. M. (1987). Differentiation of axon-related Schwann cells in vitro. I. Ascorbic acid regulates basal lamina assembly and myelin formation. J. Cell Biol. 105, 1023-34.

Eldridge, C. F., Bunge, B. M. and Bunge, R. P. (1989). Differentiation of axon related Schwann cells: II. Control of myelin formation by basal lamina. J. Neurosci. 9, 625-638.

Falls, D. L., Rosen, K. M., Corfas, G., Lane, W. S. and Fischbach, G. D. (1993). ARIA, a protein that stimulates acetylcholine receptor synthesis, is a member of the Neu ligand family. Cell 72, 801-815.

Frank, E. and Sanes, J. R. (1991). Lineage of neurons and glia in chick dorsal root ganglia: analysis in vivo with a recombinant retrovirus. Development 111, 895-908.

Fraser, S. E. and Bronner-Fraser, M. (1991). Migrating neural crest cells in the trunk of the avian embryo are multipotent. Development 112, 913-920.

Gavrilovic, J., Brennan, A., Mirsky, R. and Jessen, K. R. (1995). Fibroblast growth factors and insulin growth factors combine to promote survival of rat Schwann cell precursors without induction of DNA synthesis. European J. Neurosci. 7, 77-85.

Holmes, W. E., Sliwkowski, M. X., Akita, R. W., Henzel, W. J., Lee, J., Park, J. W., Yansura, D., Abadi, N., Raab, H., Lewis, G. D., et al. (1992). Identification of heregulin, a specific activator of p185erB2. Science 256, 1205-1210.

Jessen, K. R., Morgan, L., Stewart, H. J. S. and Mirsky, R. (1990). Three markers of adult non-myelin-forming Schwann cells, 217c(Ran-1), A5E3 and GFAP: development and regulation by neuron-Schwann cell interactions. Development 109, 91-103

Jessen, K. R. and Mirsky, R. (1991). Schwann cell precursors and their development. Glia 4, 185-194.

Jessen, K. R., Brennan, A., Morgan, L., Mirsky, R., Kent, A., Hashimoto, Y. and Gavrilovic, J. (1994). The Schwann cell precursor and its fate: a study of cell death and differentiation during gliogenesis in rat embryonic nerves. Neuron 12, 509-527.

Le Douarin, N. (1986). Cell line segregation during peripheral nervous system ontogeny. Science 231, 1515-1522.
Le Douarin, N., Dulac, C., Dupin, E. and Cameron-Curry, P. (1991) Glial cell lineages in the neural crest. Glia 4, 175-184.

Lemke, G. and Chao, M. (1988). Axons regulate Schwann cell expression of the major myelin and NGF receptor genes. Development 102, 499.

Marchionni, M. A., Goodearl, A. D. J., Chen, M. S., BerminghamMcDonogh, O., Kirk, C., Hendricks, M., Danehy, F., Misumi, D., Sudhalter, J., Kobayashi, K, et al. (1993). Glial growth factors are alternatively spliced erB2 ligands expressed in the nervous system. Nature 362, 312-318.

Meyer, D. and Birchmeier, C. (1994). Distinct isoforms of neuregulin are expressed in mesenchymal and neuronal cells during mouse development. Proc. Natl. Acad. Sci. USA 91, 1064-1068.

Meyer, D. and Birchmeier, C. (1995). Multiple essential functions of neuregulin in development. Nature 378, 386-390.

Mirsky, R., Winter, J., Abney, E. R., Pruss, R. M., Gavrilovic, J. and Raff, M. C. (1980). Myelin-specific proteins and glycolipids in rat Schwann cells and oligodendrocytes in culture. J. Cell Biol. 84, 483-94.

Monuki, E. S., Weinmaster, G., Kuhn, R. and Lemke, G. (1989). SCIP: A glial POU domain gene regulated by cyclic AMP. Neuron 3, 783-793.

Monuki, E. S., Kuhn, R., Weinmaster, G., Trapp, B. D. and Lemke, G. (1990). Expression and activity of the POU transcription factor SCIP. Science 249, 1300-1303.

Morgan, L., Jessen, K. R. and Mirsky, R. (1991). The effects of cAMP on differentiation of cultured Schwann cells: Progression from an early phenotype $\left(04^{+}\right)$to a myelin phenotype $\left(\mathrm{P0}^{+}, \mathrm{GFAP}^{-}, \mathrm{NGF}-\right.$ receptor-) growth inhibition. J. Cell Biol. 112, 457-467.

Morrison, S., Mitchell, L. S., Ecob-Prince, M. S., Griffiths, I. R., Thomson, C. E., Barrie, J. A. and Kirkham, D. (1991). P0 gene expression in cultured Schwann cells. J. Neurocytol. 20, 769-780.

Neuberger, T. J. and Cornbrooks, C. J. (1989). Transient modulation of Schwann cell antigens after peripheral nerve transection and subsequent regeneration. J. Neurocytol. 18, 695-710.

Orr-Urtreger, A., Trakhenbrot, L., Ben-Levy, R., Wen, D., Rechavi, G., Lonai, P. and Yarden, Y. (1993). Neural expression and chromosomal mapping of Neu differentiation factor to 8p12-21. Proc. Natl. Acad. Sci. USA 90, $1867-1871$.

Owens, G. C. and Bunge, R. P. (1989). Evidence for an early role for myelinassociated glycoprotein in the process of myelination. Glia 2, 119-128.

Placzek, M., Jessell, T. M. and Dodd, J. (1993). Induction of floor plate differentiation by contact-dependent, homeogeneic signals. Development 117, 205-218.

Raff, M. C., Abney, E., Brockes, J. P. and Hornby-Smith, A. (1978). Schwann cell growth factors. Cell 15, 813-822.

Schneider-Maunoury, S., Topilko, P., Seitanidou, T., Levi, G., CohenTannoudji, M., Pournin, S., Babinet, C. and Charnay, P. (1993). Disruption of Krox-20 results in alteration of rhombomeres 3 and 5 in the developing hindbrain. Cell 75, 1199-1214.

Topilko, P., Schneider-Maunoury, S., Levi, G., Baron-Van Evercooren, A. Chennoufi, A. B. Y., Seitanidou, T., Babinet, C. and Charnay, P. (1994). Krox-20 controls myelination in the peripheral nervous system. Nature 371, 796-799.

Trapp, B. D., Hauer, P. and Lemke, G. (1988). Axonal regulation of myelin protein mRNA levels in actively myelinating Schwann cells. J. Neurosci. 8. 3515 .

Vesque, C. and Charnay, P. (1992). Mapping functional regions of the segment-specific transcription factor Krox-20. Nucleic Acids Res. 20, $2485-$ 2492.

Weinmaster, G. and Lemke, G. (1990). Cell-specific cyclic AMP-mediated induction of the PDGF receptor. EMBO J. 9, 915-920.

Wen, D., Peles, E., Cupples, R., Suggs, S. V., Bacus, S. S., Luo, Y., Trail, G., Hu, S., Silbiger, S. M., Ben-Levy, R., et al. (1992). Neu differentiation factor: a transmembrane glycoprotein containing an EGF domain and an immunoglobulin homology unit. Cell 69, 559-572.

Wen, J. Y. M., Morshead, C. M. and van der Kooy, D. (1994). Satellite cell proliferation in the adult rat trigeminal ganglion results from the release of a mitotic protein from explanted sensory neurons. J. Cell Biol. 124, 10051015 .

Wilkinson, D. Bhatt, S., Chavrier, P., Bravo, R. and Charnay, P. (1989). Segment-specific expression of a zinc finger gene in the developing nervous system of the mouse. Nature 337, 461-464.

Wood, P. M. (1976). Separation of functional Schwann cells and neurons from normal peripheral nerve tissue. Brain Research 115, 361-375.

(Accepted 30 May 1996) 